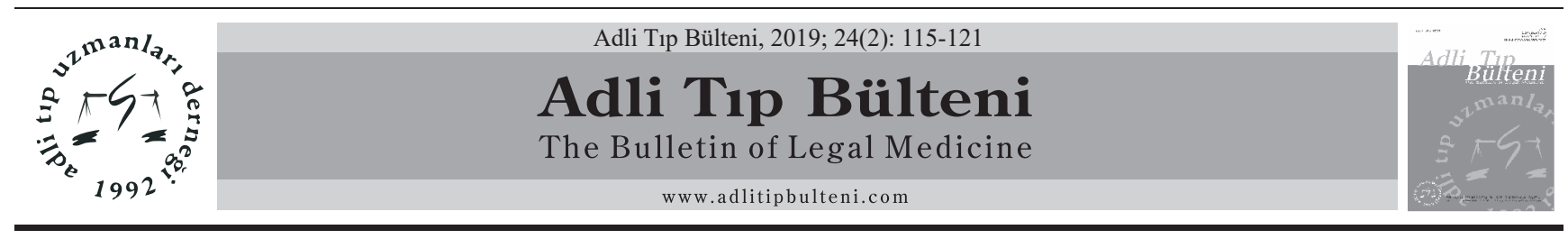

ARAŞTIRMA / RESEARCH ARTICLE

\title{
E-Zorbalık Ölçeği ve E-Mağduriyet Ölçeği: Ankara Üniversitesi Sigara Bağımlısı Öğrencilerinde Geçerlilik ve Güvenilirlik Çalışması
}

\section{E-Bulling Scale and E-Victimization Scale: The Study of Validity and Reliability of Smoking Addict Students at Ankara University}

Ebru Çetin*, Nergis Cantürk, Rukiye Dağalp

Öz

Amaç: Bu araştırmanın amacı Lam ve Li (2013) tarafindan geliştirilen Gençdoğan ve Çıkrıkçı (2015) tarafından Türkçe'ye uyarlanmış olan E-Zorbalık Ölçeği'nin ve E-Mağduriyet Ölçeği’nin geçerlilik ve güvenilirlik çalışmasını yapmaktır.

Gereç ve Yöntem: Bu çalı̧̧manın örneklemini Ankara Üniversitesi öğrencilerinden hukuk fakültesi, tıp fakültesi, mühendislik fakültesi öğrencisi olan ve sigara bağımlısı gönüllü 120 öğrenci oluşturdu. Veriler Bilgilendirilmiş Gönüllü Olur Formu, altı maddeden oluşan E-Zorbalık Ölçeği ve beş maddeden oluşan E-Mağduriyet Ölçeği ile toplandı. Verilerin analizinde içerik geçerliliği için KaiserMeyer-Olkin (KMO) ve Bartlett's Testi, güvenilirlik çalışmasında Cronbach alfa katsayısı kullanıldı.

Bulgular: E-Zorbalık Ölçeği'nde geçerlilik analiz sonucu KMO değeri \%79,8, Barlett Küresellik Testi Ki Kare değeri 323,480 olup yeterli geçerlilik düzeyine sahiptir. E-Zorbalık Ölçeği'nde Cronbach alfa katsayıs1 0,834 olup kuvvetli güvenilirlik derecesine sahip olduğu belirlendi. E-Mağduriyet Ölçeği’nde geçerlilik analiz sonucu KMO değeri \%73,9, Barlett Küresellik Testi Ki Kare değeri 224,418 bulundu. E-Mağduriyet Ölçeği'nde Cronbach alfa katsayısı 0,808 olup kuvvetli güvenilirlik derecesine sahip olduğu belirlendi.

Sonuç: Gençdoğan ve Çıkrıkçı tarafindan Türkçe'ye uyarlanmış olan E-Zorbalık Ölçeği ve E-Mağduriyet Ölçeği yüksek seviyede güvenilirlik ve yeterli geçerlilik seviyesine sahiptir. Ölçeğin sigara bağımlısı üniversite öğrencilerinin siber mağduriyet yaşama ve siber zorbalık gösterme durumlarının saptanmasında kullanılması önerilmektedir.

Anahtar sözcükler: Geçerlilik; Güvenilirlik; Siber Mağduriyet; Siber Zorbalık; Üniversite Öğrencisi.

Abstract

Objective: The aim of this study is to make the validity and reliability studies of E-Bullying Scale and E-Victimization Scale developed by Lam and Li (2013), adapted into Turkish by Gençdoğan and Çıkrıkçı (2015) in Ankara University smoking addict students.

Materials and Methods: The sample of this study consisted of 120 voluntary students from Ankara University who were smoking addict students of faculty of law, faculty of medicine and engineering faculty. The study data were collected with the Informed Voluntary Form and E-Bullying Scale consisting of six items, the E-Victimization scale consisting of five items. KMO and Bartlett's test were used for content validity and Cronbach alpha coefficient was used for data reliability.

Results: As a result of the validity analysis of the E-Bullying Scale, the KMO value was $79,8 \%$, the Barlett's Test of Sphericity chi-square value was found to be 323,480 . The Cronbach alpha coefficient of the E-Bullying Scale was 0,834 and it was found to have a strong degree of reliability. As a result of the validity analysis of the E-Victimization Scale, the KMO value was $73,9 \%$ and the Barlett's Test of Sphericity chi-square value was found to be 224,418 . The Cronbach alpha coefficient of the E-Victimization Scale was 0,808 and it was found to have a strong degree of reliability.

Conclusion: The E-Bullying Scale and E-Victimization Scale adapted into Turkish by Gençdoğan and Çıkrıkçı have a high level of reliability and sufficient validity. The scale is recommended to be used for cases of the cyber bullying and cyber victimization of smoking addict university students.

Keywords: Validity; Reliability; Cyber Victimization; Cyber Bullying; University Student.
DOI: $10.17986 /$ blm.2019252290

Ebru Çetin: Ankara Üniversitesi Adli Bilimler Enstitüsü Kriminalistik Anabilim Dalı, Ankara

Eposta: ebrucetin3453944@gmail.com ORCID iD: https://orcid.org/ 0000-00023763-4600

Nergis Cantürk: Prof. Dr., Ankara Üniversitesi Adli Bilimler Enstitüsü Kriminalistik Anabilim Dal, Ankara Eposta: nergiscanturk@yahoo.com ORCID iD: https://orcid.org/ 0000-00018739-0723

Rukiye Dağalp: Doç. Dr., Ankara Üniversitesi Fen Fakültesi İstatistik Anabilim Dalı, Ankara Eposta: rukiyedagalp@gmail.com ORCID iD: https://orcid.org/ 0000-00027335-8578

Bildirimler/ Acknowledgement:

Yazarlar bu makale ile ilgili herhangi bir çıkar çatışması bildirmemişlerdir.

The authors declare that they have no conflict of interests regarding content of this article.

Yazarlar bu makale ile ilgili herhangi bir finansal destek bildirmemişlerdir.

The Authors report no financial support regarding content of this article.

Geliş: 25.03 .2019

Düzeltme: 02.04.2019

Kabul: 22.04.2019

p-ISSN: $1300-865 \mathrm{X}$

e-ISSN: $2149-4533$ 


\section{Giriş}

İnsanoğlunun yeryüzünde var olduğu günden itibaren ortaya çıkıp günümüze kadar gelen saldırganlık yaşamın tüm alanlarında farklı şekillerde karşımıza çıkar. Saldırganlık, canlı veya cansız bir varlığa karşı fiziksel ya da duygusal zarar verme amaçlı davranış olarak tanımlanır (1). Son teknolojik gelişmelerle saldırganlık gerçek dünyadan sanal dünyaya taşınmıştır. Siber zorbalık çeşitli yönleriyle geleneksel zorbalıktan ayrılmaktadır. Sanal ortamda kimliğini gizleme, mağdur veya zorba nerede olursa olsun istediği her an her yerde iletişim kurabilme, kısa sürede birçok kişiye ulaşabilme ve mağduru inciten veri veya materyali uzun süre diğer insanların erişimine açık halde tutabilme durumları, siber zorbalığı geleneksel zorbalıktan daha tehlikeli hale getirmekte ve kontrolünü güçleştirmektedir $(2,3)$.

Siber zorbalık, bir ya da daha fazla kişinin elektronik iletişim araçları ile bir kişi veya gruba karşı belirli bir zamanda tekrar eden biçimde, kasıtlı olarak ve teknik bir tarzda yapılan psikolojik, sosyal, sözel veya görsel olarak yapılan saldırganca davranış olarak tanımlanmaktadır (4). Siber zorbalık içeren eylemlere örnek olarak; nedensiz yere bir kişiyi sohbet odasından atma veya sohbet odasında incitici tarzda davranışlarda bulunma, cep telefonuyla gizlice utanç verici fotoğraflarını çekme, birisini kötüleyen ya da utandıran web sayfaları hazırlama, mağdurun web sayfasına ya da bloglarına incitici, küçük düşürücü, tehdit edici mesajlar ya da resimler ekleme, kameralı cep telefonları aracılığ 1 ile mağdurların uygunsuz görüntülerini sanal ortama aktarma, sanal ortamda mağdura ilişkin dedikodular yayma ve mağduru kasıtlı olarak sanal ortamda düzenlenen etkinliklerden dişlama verilebilir $(5,6)$. Siber mağduriyet, bir birey veya grubun ya da özel veya tüzel bir kişiliğin, bilişim araçları vasıtasıyla teknik ya da ilişkisel tarzda kasıtlı olarak yapılan zarar verici davranışlara maruz kalması ve bunun sonucunda maddi veya manevi olarak mağduriyet yaşamasidır (7).

Siber zorbalığın; kimliğini gizleme, güç dengesizliği, sanal alanın yeterince denetlenmemesi, siber zorbalık içeren materyalin saklanabilmesi, zorbalık içeren veri veya materyalin kısa sürede çok fazla kişiye iletilebilmesi gibi özellikleri vardır (8). Güç dengesizliğine örnek olarak siber mağdurun kendisini hedef alan sanal içeriği kaldırmaları konusunda diğer insanları zorlayacak gücünün veya yaptırımının bulunmaması, siber zorbanın bilişim ve iletişim teknolojilerini kullanmada siber mağdurdan daha iyi olması ve siber zorbanın sanal ortamda siber mağdurdan daha yüksek statüye sahip olması, siber zorbanın veriyi veya materyali ulaştırabileceği çok fazla kişinin olması verilebilir (9).
Gençlik, çocuklukla erişkinlik arasında yer alan yaşama hazırlık dönemidir. Hızlı büyüme ve gelişmenin, ruhsal olgunlaşmanın yaşandığı dönemdir. Dünya Sağlık Örgütü’nün tanımına göre 10-24 yaş grubu arasındaki bireyler genç olarak kabul edilmektedir $(10,11)$. Yüksek öğrenim yıllarına rastlayan 18-25 yaş arası; bireyin ergenlik çağının bir parçası olup, genç yetişkin olmaya çabaladığı dönemdir (12). Bilgisayar ve internet kullanımı oranlarının en yüksek bulunduğu yaş grubu 16-24'tür (13). Birçok eğlence kaynağına erişimin gençlerde heyecan yaratması onların internete ayırdıkları zamanın artmasına sebebiyet vermektedir $(14,15)$. Bilişim ve iletişim teknolojilerinin bu denli hızlı geliştiği bir dönemde yetişmeleri, günümüz ergenlerine birçok kolaylık ve avantaj sağlamasının yanında birçok olumsuzluğun da ortaya çıkmasına sebebiyet vermiştir. Bilişim ve iletişim teknolojisine erişimin artmasıyla birlikte, ergenler arasında görülen saldırganlık, şiddet ve zorbalık sanal dünyaya taşınmıştır (8). Ergenler bilişim ve iletişim teknolojileri aracılı̆̆ıyla siber tacize ve zorbalığa maruz kalma, kişisel bilgilerin izinsiz sanal ortamda paylaşılması, uygunsuz görüntülerinin pornografik sitelerde yayınlanması ve zararlı içeriğe sahip sayfalara erişim gibi birçok riskle karşı karşıyadır (8). Yapılan araştırmalar siber zorbalığın ergenlikte zirve yaptığını bildirmektedir $(16,17)$.

Üniversite dönemine rastlayan $18-25$ yaş aralığının siber mağduriyet yaşama ve siber zorbalık gösterme açısından risk oluşturması sebebiyle çalışmamızda E-Zorbalık Ölçeği ve E-Mağduriyet Ölçeği Ankara Üniversitesi öğrencilerinde uygulanmıştır.

\section{Gerec ve Yöntem}

Bu araştırmanın amacı Ankara Üniversitesi sigara bağımlısı öğrencilerinin siber mağduriyet yaşama ve siber zorbalık gösterme durumlarını saptamak için, Lam ve Li (2013) tarafından geliştirilen Gençdoğan ve Çıkrıkçı (2015) tarafından Türkçe'ye uyarlanmış E-Zorbalık ÖIçeği ve E-Mağduriyet Ölçeğinin geçerlilik ve güvenilirliğini yapmaktır. E-Zorbalık Ölçeği ve E-Mağduriyet Ölçeği ile araştırma yapmak için yazar Özkan Çıkrıkçı'dan yazılı izin alındı. Ankara Üniversitesi Hukuk Fakültesi Dekanlığından, Ankara Üniversitesi Tıp Fakültesi Dekanlığından, Ankara Üniversitesi Mühendislik Fakültesi Dekanlığından öğrencilerine ölçeğin uygulanması için gerekli izinler alındı. Araştırma Ankara Üniversitesi Etik Kurulu'nun 25.06.2018 tarih ve 10/155 say1l Etik Kurul Kararı ile gerçekleştirildi. Araştırmanın evrenini Ankara Üniversitesinde eğitimine devam eden tüm öğrenciler oluşturdu. Sigara bağımlılığı toplumumuzda en yaygın görülen bağımlılık türüdür. Diğer bağımlılıklarla ilişkisini değerlendirmeye alacak ileri araştırmalara veri sağlaması 
amacıyla örneklemimizi sigara bağımlısı üniversite öğrencileri oluşturmuştur. Araştırmanın örneklemini Ekim 2018-Ocak 2019 tarihleri arasında ulaşılabilen, araștırmaya gönüllü olarak katılan ve sigara bağımlısı, Ankara Üniversitesi tıp, mühendislik ve hukuk fakültelerinde öğrenim gören 120 öğrenci oluşturdu. Araştırmaya katılan 120 öğrencinin 40’1 $(\% 33,3)$ tıp fakültesi, 40’1 $(\% 33,3)$ hukuk fakültesi, 40'1 $(\% 33,3)$ mühendislik fakültesi öğrencisidir. Veriler araştırmacı tarafindan öğrenciler ile yüz yüze görüşülerek toplandı. Verilerin istatistiksel analizi SPSS 21.0 programında yapıldı. E-Zorbalık Ölçeği'nin ve E-Mağduriyet Ölçeği'nin Ankara Üniversitesi'nin sigara bağımlısı öğrencileri ile geçerlilik ve güvenilirlik çalışması yapıldı. Verilerin analizinde içerik geçerliliği için KMO ve Bartlett's Testi, güvenilirlik çalışmasında Cronbach alfa katsayısı kullanıldı.

\subsection{Veri Toplama Araçları}

\section{a) Bilgilendirilmiş Gönüllü Olur Formu}

Araştırmanın tanımının ve amacının anlatıldı̆̆ı, araştırmada izlenilecek yöntemlerin belirtildiği formdur. $\mathrm{Bu}$ formda ayrıca araştırmaya katılacakların gizlilik ve güvenliğinin sağlanacağı teminatı verilmiştir. $\mathrm{Bu}$ formda araştırmaya katılmanın gönüllülüğe bağlı olduğu da belirtilmiştir.

\section{b) E-Zorbalık Ölçeği ve E-Mağduriyet Ölçeği}

Lam ve Li (2013) tarafindan ergenler arasındaki e-zorbalığ 1 ve e-mağduriyeti incelemek amaciyla geliştirilmiş olup, Gençdoğan ve Çıkrıkçı (2015) tarafından Türkçe'ye uyarlanmıştır (18). Gençdoğan ve Çıkrıkçı 163 lise öğrencisi ile yaptıkları çalışmada E-Zorbalık

Tablo 1. E-Zorbalık Ölçeğinin Güvenilirlik Analizi

\begin{tabular}{|c|c|c|c|c|c|c|c|}
\hline \multicolumn{8}{|c|}{ Güvenilirlik İstatistikleri } \\
\hline \multirow{2}{*}{\multicolumn{2}{|c|}{$\begin{array}{r}\text { Cronbach's Alpha Katsayıs1 } \\
\text { Madde Sayıs1 }\end{array}$}} & \multicolumn{6}{|l|}{0,834} \\
\hline & & \multicolumn{6}{|l|}{6} \\
\hline \multicolumn{8}{|c|}{ Madde- Toplam İstatistikleri } \\
\hline & & $\begin{array}{l}\text { Madde } \\
\text { Silindiğinde } \\
\text { Ölçek } \\
\text { Ortalamas1 }\end{array}$ & \multicolumn{2}{|c|}{$\begin{array}{l}\text { Madde Silindiğinde } \\
\text { Ölçek Varyansı }\end{array}$} & $\begin{array}{l}\text { Düzeltilmiş } \\
\text { Madde- } \\
\text { Toplam } \\
\text { Korelasyonu }\end{array}$ & \multicolumn{2}{|c|}{$\begin{array}{l}\text { Madde Silindiğinde } \\
\text { Cronbach's Alpha } \\
\text { Katsayıs1 }\end{array}$} \\
\hline \multicolumn{2}{|c|}{$\begin{array}{l}\text { Facebook ve twitter gibi sosyal ağlar, kısa mesajlar } \\
\text { ve e- mail yoluyla başkalarını kaç kez rahatsız } \\
\text { ettiniz? }\end{array}$} & 3,3167 & & 26,538 & 0,732 & & 0,782 \\
\hline \multicolumn{2}{|c|}{$\begin{array}{l}\text { Facebook ve twitter gibi sosyal ağlar, kısa mesajlar } \\
\text { ve e- mail yoluyla başkalarını kaç kez kötü bir } \\
\text { isimle çağırdınız? }\end{array}$} & 2,7583 & & 23,563 & 0,62 & & 0,816 \\
\hline \multicolumn{2}{|c|}{$\begin{array}{l}\text { Facebook ve twitter gibi sosyal ağlar, kısa mesajlar } \\
\text { ve e- mail yoluyla başkalarına kaç kez ahlaksız } \\
\text { şeyler söylediniz? }\end{array}$} & 2,975 & & 25,672 & 0,603 & & 0,811 \\
\hline \multicolumn{2}{|c|}{$\begin{array}{l}\text { Facebook ve twitter gibi sosyal ağlar, kısa mesajlar } \\
\text { ve e- mail yoluyla başkalarına kaç kez onları } \\
\text { inciteceğinizi ya da döveceğinizi söylediniz? }\end{array}$} & 3,2417 & & 26,269 & 0,81 & & 0,769 \\
\hline \multicolumn{2}{|c|}{$\begin{array}{l}\text { Facebook ve twitter gibi sosyal ağlar, kısa mesajlar } \\
\text { ve e- mail yoluyla başkalarını kaç kez tehdit ettiniz? }\end{array}$} & 3,325 & & 27,885 & 0,649 & & 0,799 \\
\hline \multicolumn{2}{|c|}{$\begin{array}{l}\text { Facebook ve twitter gibi sosyal ağlar, kısa mesajlar } \\
\text { ve e- mail yoluyla birilerinin başkaları tarafından } \\
\text { sevilmemesini sağlamak için bir şeyler uydurdun } \\
\text { mu? }\end{array}$} & 3,6333 & & 35,596 & 0,34 & & 0,851 \\
\hline \multicolumn{8}{|c|}{ Sinıf İçi Korelasyon Katsayısı } \\
\hline & \multirow[t]{2}{*}{ Sınıf İçi Korelasyon } & \multicolumn{2}{|c|}{$\% 95$ Güven Aralığı } & \multicolumn{4}{|c|}{0 Gerçek Değerli F Testi } \\
\hline & & Alt Sinır & $\begin{array}{l}\text { Üst } \\
\text { Sinır }\end{array}$ & Değer & df1 & df 2 & Sig \\
\hline Tek Ölçüler & 456 & 0,376 & 0,541 & 6,02 & 119 & 595 & 0 \\
\hline $\begin{array}{l}\text { Ortalama } \\
\text { Ölçüler }\end{array}$ & 834 & 0,783 & 0,876 & 6,02 & 119 & 595 & 0 \\
\hline
\end{tabular}


Ölçeği'nin Türkiye'de Cronbach alfa katsayısının 0,75 olduğunu tespit etmişlerdir (18). Gençdoğan ve Çıkrıkçı 188 lise öğrencisi ile yaptıkları çalışmada Cronbach alfa katsayısının 0,79 olduğunu tespit etmişlerdir (18).

E-Zorbalık Ölçeği altı maddeden, E-Mağduriyet Ölçeği beş maddeden oluşmaktadır. Her iki ölçek içinde S1fir Kez (0), Bir Kez (1), İki Kez (2), Üç kez (3), Dört Kez (4), Beş Kez (5), Altı Kez ve Daha Fazlası (6) şeklindeki derecelendirme kullanılmıştır (18).

\section{Bulgular}

a) E-Zorbalık Öıçeğinin Güvenilirlik Çalışması

E-Zorbalık Ölçeğinin Cronbach alfa katsayısı 0,834 olarak, sınıf içi korelasyon katsayısı (ortalama ölçüler) da 0,834 olarak belirlendi (Tablo 1). E-Zorbalık Ölçeğinin madde çıkarıldığındaki Cronbach alfa değerlerinin 0,7690,851 arasında değiştiği tespit edildi (Tablo 1 ). Ayrıca E-Zorbalık Ölçeğinin düzeltilmiş madde toplam puan korelasyon katsayılarının $0,340-0,810$ arasında değiştiği belirlendi (Tablo 1). b) E-Mağduriyet Ölçeğinin Güvenilirlik Çalışması

E-Mağduriyet Ölçeğinin Cronbach alfa katsayısı 0,808 olarak, sınıf içi korelasyon katsayısı (ortalama ölçüler) da 0,808 olarak belirlendi (Tablo 2).

E-Mağduriyet Ölçeğinin madde çıkarıldığındaki Cronbach alfa değerlerinin 0,735-0,796 arasında değiştiği saptandı. E-Mağduriyet Ölçeğinin düzeltilmiş madde toplam puan korelasyon katsayılarının da 0,512-0,721 arasında değiştiği belirlendi (Tablo 2).

\section{c) E-Zorbalık Ölçeğinin Geçerlilik Çalışması}

Verilerin analizinde içerik geçerliliği için KMO ve Bartlett's Testi kullanıldı. Ölçeğin geçerlilik analiz sonucunda KMO değeri 0,798 ve Barlett Küresellik Testi Ki Kare değeri 323,480 df(15) (Sig=,000) bulundu (Tablo 3).

\section{d) E-Mağduriyet Ölçeğinin Geçerlilik Çalışması}

Verilerin analizinde içerik geçerliliği için KMO ve Bartlett's Testi kullanıldı. Ölçeğin geçerlilik analiz sonucunda KMO değeri 0,739 ve Barlett Küresellik Testi Ki Kare değeri 224,418 df(10) (Sig=,000) bulundu (Tablo 4).

Tablo 2. E-Mağduriyet Ölçeğinin Güvenilirlik Analizi

\begin{tabular}{|c|c|c|c|c|c|c|c|}
\hline \multicolumn{8}{|c|}{ Güvenilirlik İstatistikleri } \\
\hline \multicolumn{2}{|c|}{ Cronbach's Alpha Katsayısı } & \multicolumn{6}{|l|}{0,808} \\
\hline \multicolumn{2}{|r|}{ Madde Sayıs1 } & \multicolumn{6}{|l|}{5} \\
\hline \multicolumn{8}{|c|}{ Madde-Toplam İstatistikleri } \\
\hline & & $\begin{array}{c}\text { Madde } \\
\text { Silindiğinde } \\
\text { Ölçek Ortalaması }\end{array}$ & \multicolumn{2}{|c|}{$\begin{array}{c}\text { Madde } \\
\text { Silindiğinde Ölçek } \\
\text { Varyansı }\end{array}$} & $\begin{array}{l}\text { Düzeltilmiş } \\
\text { Madde- Toplam } \\
\text { Korelasyonu }\end{array}$ & \multicolumn{2}{|c|}{$\begin{array}{l}\text { Madde Silindiğinde } \\
\text { Cronbach's Alpha } \\
\text { Katsayis1 }\end{array}$} \\
\hline \multicolumn{2}{|c|}{$\begin{array}{l}\text { Facebook ve twitter gibi sosyal ağlar, } \\
\text { kısa mesajlar ve e- mail yoluyla başkaları } \\
\text { tarafından kaç kez rahatsız edildiniz? }\end{array}$} & 3,7833 & & 26,978 & 0,512 & & 0,796 \\
\hline \multicolumn{2}{|c|}{$\begin{array}{l}\text { Facebook ve twitter gibi sosyal ağlar, } \\
\text { kısa mesajlar ve e- mail yoluyla başkaları } \\
\text { tarafindan kaç kez kötü bir isimle çağrıldınız? }\end{array}$} & 4,0333 & & 27,31 & 0,544 & & 0,786 \\
\hline \multicolumn{2}{|c|}{$\begin{array}{l}\text { Facebook ve twitter gibi sosyal ağlar, kısa } \\
\text { mesajlar ve e- mail yoluyla başkaları size } \\
\text { ahlaksız şeyler söylediler? }\end{array}$} & 3,6167 & & 23,196 & 0,606 & & 0,773 \\
\hline \multicolumn{2}{|c|}{$\begin{array}{l}\text { Facebook ve twitter gibi sosyal ağlar, kısa } \\
\text { mesajlar ve e- mail yoluyla baškaları sizi kaç } \\
\text { kez inciteceğini ya da döveceğini söylediler? }\end{array}$} & 4,3167 & & 25,512 & 0,721 & & 0,735 \\
\hline \multicolumn{2}{|c|}{$\begin{array}{l}\text { Facebook ve twitter gibi sosyal ağlar, kısa } \\
\text { mesajlar ve e- mail yoluyla başkaları sizi kaç } \\
\text { kez tehdit etti? }\end{array}$} & 4,45 & & 27,308 & 0,633 & & 0,763 \\
\hline \multicolumn{8}{|c|}{ Sınıf İçi Korelasyon Katsayısı } \\
\hline & \multirow[t]{2}{*}{ Sınıf İçi Korelasyon } & \multicolumn{2}{|c|}{ \%95 Güven Aralığ 1} & \multicolumn{4}{|c|}{0 Gerçek Değerli F Testi } \\
\hline & & Alt Sinır & $\begin{array}{l}\text { Üst } \\
\text { Sinır }\end{array}$ & Değer & df1 & df 2 & Sig \\
\hline Tek Ölçüler & ,457 & 0,372 & 0,546 & 5,207 & 119 & 476 & 0 \\
\hline $\begin{array}{l}\text { Ortalama } \\
\text { Ölçüler }\end{array}$ & ,808 & 0,748 & 0,857 & 5,207 & 119 & 476 & 0 \\
\hline
\end{tabular}


Tablo 3. E-Zorbalık Ölçeğinin Geçerlilik Analizi

\begin{tabular}{|c|c|c|}
\hline \multicolumn{3}{|c|}{ KMO ve Bartlett's Testi } \\
\hline \multicolumn{2}{|c|}{$\begin{array}{l}\text { Kaiser-Meyer-Olkin Örnekleme Yeterliliğinin } \\
\text { Ölçülmesi }\end{array}$} & ,798 \\
\hline \multirow{3}{*}{$\begin{array}{l}\text { Bartlett's Küresellik } \\
\text { Testi }\end{array}$} & Yaklaşık Ki-Kare & 323,480 \\
\hline & Df & 15 \\
\hline & Sig. &, 000 \\
\hline
\end{tabular}

Zorbalık geçerlilik analizi sonucu; \%79.8 olarak bulundu.

Tablo 4. E-Mağduriyet Ölçeğinin Geçerlilik Analizi

\begin{tabular}{|l|l|r|}
\hline \multicolumn{2}{|c|}{ KMO ve Bartlett's Testi } \\
\hline $\begin{array}{l}\text { Kaiser-Meyer-Olkin Örnekleme Yeterliliğinin } \\
\text { Ölçülmesi }\end{array}$ &, 739 \\
\hline Bartlett's Küresellik Testi & $\begin{array}{l}\text { Yaklaş1k } \\
\text { Ki-Kare }\end{array}$ & 224,418 \\
\cline { 2 - 3 } & Df & 10 \\
\cline { 2 - 3 } & Sig. &, 000 \\
\hline
\end{tabular}

Mağduriyet geçerlilik analizi sonucu; \%73.9 olarak tespit edildi.

\section{Tartışma}

Çalışmamızda E-Zorbalık Ölçeği'nin düzeltilmiş madde toplam puan korelasyon katsayılarının 0,3400,810 arasında değiştiği belirlenmiş (Tablo 1) olup, E-Mağduriyet Ölçeği'nin düzeltilmiş madde toplam puan korelasyon katsayılarının 0,512-0,721 arasında değiştiği saptanmıştır (Tablo 2). Ayrıca çalışmamızda E-Zorbalık Ölçeği'nin Cronbach alfa katsayısı 0,834 olarak belirlenmiştir (Tablo 1). Gençdoğan ve Çıkrıkçı (18), E-Zorbalık Ölçeği'ni Türkiye'de 2012-2013 eğitim öğretim yılı güz döneminde, yaşları 14 ile 19 arasında değişen 163 lise öğrencisine uygulamıştır. Gençdoğan ve Çıkrıkçı'nın yaptığı çalışmada Cronbach alfa katsayısı 0,75 bulunmuştur. Çalışmamızda ise E-Mağduriyet Ölçeği'nin Cronbach alfa katsayısı 0,808 olarak belirlendi (Tablo 2). Gençdoğan ve Çıkrıkçı (18) E-Mağduriyet Ölçeği'ni ise Türkiye'de 2012-2013 eğitim öğretim yllı güz döneminde, yaşları 14 ile 19 arasında değişen 188 lise öğrencisine uygulamıştır. Gençdoğan ve Çıkrıkçı'nın yaptı̆̆ı çalışmada Cronbach alfa katsayısı 0,79 bulunmuştur.

Çalışmamızda E-Zorbalık Ölçeği'nin sınıf içi korelasyon katsayıs1 0,834 olarak (Tablo 1), E-Mağduriyet Ölçeği'nin sınıf içi korelasyon katsayısı ise 0,808 olarak (Tablo 2) belirlendi. Çalışmamızda yapı geçerliliği incelenmiştir. Çalışma grubundan elde edilen verilerin açımlayıcı faktör analizine uygun olup olmadığı KaiserMeyer-Olkin (KMO) ve Barlett testi ile incelenmiştir. Çalışmamızda E-Zorbalık Ölçeği'nin KMO değeri 0,798 ve Barlett Küresellik Testi Ki Kare değeri 323,480 df(15) ( $\mathrm{Sig}=, 000$ ) bulunmuş (Tablo 3) olup, E-Mağduriyet Ölçeği'nin KMO değeri 0,739 ve Barlett Küresellik Testi
Ki Kare değeri 224,418 df(10) (Sig=,000) olarak (Tablo 4) tespit edilmiş̧ir.

Siber mağduriyet ve zorbalığın saptanması amaciyla kullanılan farklı ölçekler mevcuttur. 19 maddeden oluşan Siber Mağduriyet Ölçeği'nin 3159 ergen ile geçerlilik ve güvenilirlik çalışmasını Alvarez ve arkadaşları 2017'de yapmıştır (19). Ölçeğin dört faktörü (kişiliğini gizleme, görsel-cinsel siber mağduriyet, yazıll-sözlü siber mağduriyet, çevrimiçi dışlanma) vardır. Ölçeğin iç tutarlılığını ölçmede Rayhov Rho katsayısı kullanılmıştır. Yapılan çalışmada dört faktörün her birinin Rayhov Rho katsayısı değerinin 0,74 ile 0,89 arasında değiştiği saptanmıştır. Geçerlilik çalışmasında ölçeğin dört faktörü ile üç dış kriter (İnternet Risk Davranışları, Çevrimdışı Okul Mağduriyeti, Benlik Saygısı) arasında korelasyona bakılmış ve ölçeğin dört faktörü ile üç dış kriter arasında istatistiksel ve anlamlı korelasyon saptanmıştır. Ölçeğin İnternet Risk Davranışları ve Çevrimdışı Okul Mağduriyeti arasında pozitif ilişki, Benlik Saygısı arasında negatif ilişki saptanmıştır. 19 maddeden oluşan Siber Saldırganlık Ölçeği'nin 3148 ergen ile geçerlilik ve güvenilirlik çalışmasını Alvarez ve arkadaşları 2016 yılında yapmıştır (20). Ölçeğin üç faktörü (kişiliğini gizleme, görsel-cinsel siber saldırganlık, sözlü siber saldırganlık ve dışlanma) vardır. Ölçeğin iç tutarlılığını ölçmede Rayhov Rho katsayısı kullanılmıştır. Yapılan çalışmada üç faktörün her birinin Rayhov Rho katsayısı değerinin 0,809 ile 0,932 arasında değiştiği saptanmıştır. Geçerlilik çalışmasında Ölçeğin üç faktörü ile üç dış kriter (okul ortamındaki fiziksel saldırganlık sıklı̆ğ, dürtülerine hâkim olamama, empati) arasında korelasyona bakılmış ve üç faktörü ile üç dış kriter arasında istatistiksel ve anlamlı korelasyon saptanmıştır. Ölçek ile okul ortamındaki fiziksel saldırganlık sıklığı, dürtülerine hâkim olamama arasında pozitif ilişki, empati ile negatif ilişki saptanmıştır.

Siber Mağduriyet Ölçeği, Çetin ve arkadaşları (21) tarafindan 2011 y1lında geliştirilmiştir. 22 sorudan ve üç alt boyuttan (siber dilsel zorbalık, kimliğini gizleme, siber sahtecilik) oluşmaktadır. Çetin ve arkadaşları 404 öğrenci ile ölçeğin geçerlilik ve güvenilirlik çalışmasını yaptıklarında, ölçeğin Cronbach alfa katsayısını 0,89 olarak saptamışlardır. Ölçeğin alt boyutlarının Cronbach alfa değerleri; siber dilsel zorbalık için 0,80 , kimliğini gizleme için 0,68 ve siber sahtecilik için 0,86 olarak saptanmıştır. Ölçeğin test-tekrar test güvenilirliği değeri 0,85 olarak tespit edilmiştir. Ölçeğin alt boyutlarının test-tekrar test güvenilirliği değerleri; siber dilsel zorbalık için 0,80 , kimliğini gizleme için 0,69 ve siber sahtecilik için 0,87 olarak belirlenmiştir. Yapılan çalışma sonucunda ölçeğin yeterli güvenilirlik ve tatmin edici geçerliliğe sahip olduğu saptanmıştır. Çetin ve arkadaşları 
tarafından geliştirilen Siber Zorbalık Ölçeği, 22 sorudan ve üç alt boyuttan (siber dilsel zorbalık, kimliğini gizleme, siber sahtecilik) oluşmaktadır. Çetin ve arkadaşları ölçeğin geçerlilik ve güvenilirlik çalışmasını yaptıklarında, ölçeğin Cronbach alfa katsayısını 0,89 olarak saptamışlardır. Ölçeğin alt boyutlarının Cronbach alfa değerleri; siber dilsel zorbalık için 0,81 , kimliğini gizleme için 0,69 ve siber sahtecilik için 0,83 olarak saptanmıştır. Ölçeğin test-tekrar test güvenilirliği değerleri 0,90 olarak tespit edilmiştir. Ölçeğin alt boyutlarının test-tekrar test güvenilirliği değerleri; siber dilsel zorbalık için 0,73 , kimliğini gizleme için 0,72 ve siber sahtecilik için 0,86 olarak saptanmıştır. Yapılan çalışma sonucunda ölçeğin yeterli güvenilirlik ve tatmin edici geçerliliğe sahip olduğu saptanmıştır.

Arıcak ve arkadaşları (22) tarafından geliştirilen ve 24 maddeden oluşan Siber Zorbalık Ölçeği geçerlilik güvenilirlik çalışması 515 öğrencinin katılımıyla yapılmıştır. Ölçeğin Cronbach alfa katsayısı 0,95 ve madde silindiğinde Cronbach alfa katsayıları ise 0,945-0,951 arasinda saptanmıştır. Ölçeğin KMO değeri 0,939 ve Bartlett Küresellik Testi değeri 9197,54 olarak saptanmıştır. Ölçeğin test-tekrar test güvenilirliği çalışması 103 öğrenci ile gerçekleştirilmiş ve test-tekrar test güvenilirliği katsayısını bulmak için Spearman Rho korelasyon tekniği kullanılmış ve değeri 0,70 olarak saptanmıştır. Arıcak ve arkadaşları (7) tarafından geliştirilen ve 24 maddeden oluşan Siber Mağduriyet Ölçeği geçerlilik güvenilirlik çalışması 532 öğrencinin katılımıyla yapılmıştır. Ölçeğin Cronbach alfa katsayıs1 0,89 ve madde silindiğinde Cronbach alfa katsayıları ise 0,879-0,886 arasında saptanmıştır. Ölçeğin KMO değeri 0,882 ve Bartlett Küresellik Testi Ki Kare değeri 4374,93 olarak saptanmıştır. Ölçeğin test- tekrar test güvenilirliği çalışması 103 öğrenci ile gerçekleştirilmiş ve test-tekrar test güvenilirliği katsayısını bulmak için Spearman Rho korelasyon tekniği kullanılmış ve değeri 0,75 olarak saptanmıştır.

\section{Sonuç}

Lam ve Li tarafindan ergenler arasındaki e-zorbalığı incelemek amacıyla geliştirilen Gençdoğan ve Çıkrıkçı tarafindan Türkçe'ye uyarlanmış E-Zorbalık Ölçeği ile Lam ve Li tarafindan ergenler arasındaki e-mağduriyeti incelemek amacıyla geliştirilen Gençdoğan ve Çıkrıkçı tarafından Türkçe'ye uyarlanmış E-Mağduriyet Ölçeği yüksek güvenilirlik ve yeterli geçerlilik düzeyindedir. Bu nedenle bu ölçeklerin sigara bağımlısı üniversite öğrencilerinin siber mağduriyet yaşama ve siber zorbalık gösterme durumlarının saptanmasında kullanılması önerilmektedir.

\section{Kaynaklar}

1. Berkowitz L. Aggression: Its Causes, Consequences, and Control. New York: Mcgraw-Hill, 1993.

2. Suler J. The online disinhibition effect. CyberPsychology \& Behavior 2004;7(3):321-6. DOI: https://doi. org/10.1089/1094931041291295.

3. Kowalski RM, Limber SP. Electronic bullying among middle school students. Journal of Adolescent Health 2007;41(6):22-30. DOI: https://doi.org/10.1016/j.jadohealth.2007.08.017.

4. Yetim S. Siber Zorbalık, Türkiye ve ABD karşılaştırması (Abd V. Drew Dosyas1). TBB Dergisi 2015;120:325-84.

5. Hinduja S, Patchin JW. Bullying, cyberbullying, and suicide. Archives of Suicide Research 2010;14(3):206-21. DOI: https://doi.org/10.1080/13811118.2010.494133.

6. Erdur-Baker Ö, Topçu Ç. Siber Zorbalık. İçinde: Deryakulu D (Ed.). Bilişism Teknolojileri Öğretiminde Sosyo-Psikolojik Değişkenler. 1. Baskı. Ankara: Maya Akademi Yayınc1lik, 2008;105-25.

7. Arıcak OT, Tanrıkulu T ve Kınay H. Siber Mağduriyet Ölceği’nin ilk psikometrik bulguları. Akdeniz Eğitim Araştırmaları Dergisi 2012;11:1-6.

8. Eroğlu Y. Ergenlerde Siber Zorbalık ve Mağduriyeti Yordayan Risk Etmenlerini Belirlemeye Yönelik Bütüncül Bir Model Önerisi. Doktora Tezi. Bursa: Uludağ Üniversitesi Eğitim Bilimleri Enstitüsü. 2014.

9. Menesini E, Nocentini A. Cyberbullying definition and measurement: Some critical considerations. Journal of Psycho$\log$ 2009;21:230-2. DOI: https://doi.org/10.1027/00443409.217.4.230.

10. Promoting the health of young people in Custody Pg. 7. http://www.euro.who.int/document/e81703.pdf Erişim tarihi: 25.12.2018.

11. Adolesanlarda Koruyucu Sağlık Hizmetleri. www.sabem. saglik.gov.tr/Akademik_Metinler/goto.aspx?id=1455 Erişim tarihi: 26.12.2018.

12. K1lıççı Y. Okulda Ruh Sağlığı. 5. Baskı. Ankara: Anı Yayınc1lık, 2006;113-5.

13. Hane Halkı Bilişim Teknolojileri Kullanım Araştırmas1, 2014. http://www.tuik.gov.tr/PreHaberBultenleri. do?id=16198 Erişim tarihi: 25.12.2018.

14. Davis RA. Cognitive-behavioral model of pathological internet use. Computers in Human Behavior 2001;17(2):18795. DOI: https://doi.org/10.1016/S0747-5632(00)00041-8.

15. Yang SC, Tung CJ. Comparison of internet addicts and nonaddicts in Taiwanese high school. Computers in Human Behavior 2007;23(1):79-96. DOI: https://doi.org/10.1016/j. chb.2004.03.037.

16. Tokunaga RS. Following you home from school: A critical review and synthesis of research on cyberbullying victimization. Computers in Human Behavior 2010;26:277-87. DOI: https://doi.org/10.1016/j.chb.2009.11.014.

17. Smith PK. Cyberbullying and Cyber Aggression. In: Jimerson SR, Neckerson AB, Mayer MJ, Furlong MJ (Eds.), Handbook of School Violence and School Saffety: Interna- 
tional Research and Practice. New York, US: Routledge/ Taylor \& Francis Group, 2012.

18. Gençdoğan B, Çıkrıkçı Ö. Reliability and validity studies of the Turkish version of the e-bullying scale (E-BS) and e-victimization scale (E-VS). Journal of Theory and Practice in Education 2015;11(1):359-73.

19. Alvarez-García D, Nú nez JC, Barreiro-Collazo A, García T. Validation of the Cybervictimization Questionnaire (CYVIC) for adolescents. Computers in Human Behavior 2017;70: 270-81. DOI: https://doi.org/10.1016/j. chb.2017.01.007.

20. Alvarez-García D, Barreiro-Collazo A, Nú nez JC, Dobarro A. Validity and reliability of the Cyber-aggression Ques- tionnaire for adolescents (CYBA). The European Journal of Psychology Applied to Legal Context 2016;8:69-77. DOI: https://doi.org/10.1016/j.ejpal.2016.02.003.

21. Çetin B, Yaman E, Peker A. Cyber Victim and Bullying Scale: A study of validity and reliability. Computers \& Education 2011;57(4):2261-71. DOI: https://doi.org/10.1016/j. compedu.2011.06.014.

22. Arıcak OT, Kınay H, Tanrıkulu T. Siber Zorbalık Ölceği'nin ilk psikometrik bulguları. Hasan Ali Yücel Eğitim Fakültesi Dergisi 2012;9(1):101-14. 